\title{
Flow-Induced Structure Change and Flow-Instability of CTAB/NaSal Aqueous Solution in a Two-Dimensional Abrupt Contraction Channel
}

\author{
Mayumi OUCHI ${ }^{*}$, Tsutomu TAKAHASHI ${ }^{* *}$, and Masataka SHIRAKASHI ${ }^{* *}$ \\ * Department of Mechanical Engineering, Graduate School of Nagaoka University of Technology \\ 1608-1 Kamotomioka Nagaoka, Niigata 940-2188, Japan \\ ${ }^{* *}$ Department of Mechanical Engineering, Nagaoka University of Technology \\ 1608-1 Kamotomioka Nagaoka, Niigata 940-2188, Japan
}

\begin{abstract}
It is known that the $\mathrm{CTAB} / \mathrm{NaSal}$ aqueous solution forms wormlike micelles when the concentration is higher than a certain value and shows the flow-induced structure change when both the shear rate and shear strain exceed respective critical values. In the present work, the start-up behavior of this surfactant solution in a two-dimensional abrupt contraction channel driven by a constant pressure was investigated. At a low driving pressure, the flow rate increases gradually and reaches an equilibrium state. When the driving pressure is higher than a certain value, the flow rate rises at a certain elapsed time. The elapsed time showing increase in flow rate shortens with increasing driving pressure. In the entry area of the narrow channel, a pair of wedge shape opaque regions appears. From the comparison with the observation in Couette flow of the same solution, it is found the opaque regions are caused by shear induced structure and the viscosity of the regions is higher than the other region. The regions grow up and make the other region with low viscosity narrower. The opaque regions suddenly break and disappear when the flow rate changes. Flow instability is induced by a sudden change of flow states. These phenomena are characteristic of the fluid showing the flow-induced structure change, whereas ordinary polymer solution do not exhibit such behavior.
\end{abstract}

Key Words: Flow-induced structure / Flow-instability / Two-dimensional abrupt contraction channel / Surfactant solution

\section{二次元急縮小流路において発生する CTAB/NaSal 水溶液の 流動誘起構造変化と流動不安定性}

\author{
大内 真由美*, 高橋 勉 ${ }^{* *}$, 白樫 正高 ${ }^{* *}$
}

（原稿受理：2006年4月7日）

\begin{abstract}
1. 緒言
紐状ミセルを形成する界面活性剤水溶液は鎖状高分子溶 液と同様に顕著な粘弾性特性を示すことが知られている.1,2) また，ある種の界面活性剤水溶液では流動によりミセルの構 造変化が生じ, 流動特性が大きく変化する.これを流動誘起 構造変化という. 3 -5) 紐状ミセルを形成する界面活性剂水溶液 はセメントの増粘剤としてすでに実用化が進んでいるが，希 薄水溶液として乱流抗力低減効果を発生させるための添加 剤などにも使用することが期待されている.

紐状ミセルを形成する界面活性剂水溶液を作動流体とし て工業的に利用するためには流動特性を明らかにする必要 がある.しかし，ミセルが絡み合い構造を示す濃厚な界面活 性剂水溶液に関しては現在のところ極めて単純な流れ場の

\footnotetext{
$*$ 長岡技術科学大学大学院工学研究科

T 940-2188 新潟県長岡市上富岡町 1603-1

E-mail:oouchi@stn.nagaokaut.ac.jp, Tel:+81 258-47-1611(ex 7343), Fax:+81 258-47-9770

** 長岡技術科学大学工学部
}

T 940-2188 新潟県長岡市上富岡町 1603-1
\end{abstract}

代表であるクエット流れにおける構造変化に関する研究が 行われている段階であり, 構造変化の化学的・物理的説明は まだ得られていない. クエット流れにより誘起される構造変 化に関しては以下のような報告がなされている。四方らのは $\mathrm{CTAB}(0.03 \mathrm{M}) / \mathrm{NaSal}(0.23 \mathrm{M})$ 水溶液の同心二重円筒型流路内の ステップ状に立ち上がるクエット流れを観察し，ずり速度が $3 \mathrm{~s}^{-1}$ 以上になるとせん断流動誘起構造変化 (Shear-Induced Structure: SIS）が生じること, および流動複屈折やずり応力に 微少な振動が現れる流動不安定性が発生することを報告し た。また，SISおよび流動不安定性の発生にはそれぞれ臨界の ひずみ量が存在し，与えるずり速度が異なる場合でも臨界ひ ずみは変化しないことを報告した，さらに， Fischer ${ }^{7) ら は ~}$ $\mathrm{CPyCl} / \mathrm{NaSal}$ 水溶液を用いて同心二重円筒流路内の定常流動 状態における流れ場を可視化し, SISにより生じる粘度増加と 同時に試料が白濁することを示した．これに対して，著者ら ${ }^{8)}$ は光学ガラス製の同心二重円筒流路を製作し, CTAB/NaSal水 溶液のスタートアップ流れにおける SIS と流動不安定性の発 生を流れの可視化により観察し，ひずみとずり速度に対する 
試料の状態変化を詳細に調べた。 その結果, ずり速度とひず みにより (1)SIS が発生せず線形な状態, (2) 白濁が発生するが 安定流動する状態, (3) 白濁が薄まるが流動複屈折がひずみに 対して線形的に変化し安定流動する状態, (4)流れ場に微小な 速度変動が発生する状態, (5)は将もどり現象を伴う強い流動 不安定性を示す状態, の五つの状態に分類できることを示し

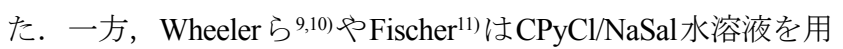
いて応力制御による実験を行い, 平行円板型流路において SIS を形成するリング状の白濁領域を観察した。そして, 流動に 伴い白濁リングは周期的に発生と消滅を繰り返し，この周期 と同期した変動がせん断応力および第一法線応力差に発生 することを報告している。また，高橋ら ${ }^{12}$ はひずみ制御にて 同様の実験を行い，白濁リングの発生を報告している．この 白濁リングの発生および消滅の周期はずり速度の増加に伴 い線形的に増加し, そのとき発生する白濁リングの内径位置 におけるずり速度は円板の角速度によらず一定となること を報告した。 すなわち平行円板型流路において発生するリン グ状の白濁領域は流路の半径に比例して増加するずり速度 が, ある臨界值を超える領域で発生し, 発生・消滅の周期性 についてもずり速度分布に起因するものであると報告して いる.

以上のようにSISの詳細な解明はまだなされていないが, $\mathrm{CTAB} / \mathrm{NaSal}$ 水溶液に関してはクエット流れにより発生する 現象, SISや流動不安定性の発生状態が定量的に報告されてい る. そこで本研究では, 界面活性剂水溶液の作動流体として の工業的利用を目指した第一歩として, より複雑な流れ場に おいてSISや流動不安定性が流れに対して及ぼす影響を調べ ることを目的とする. 流れ場としては流路内においてずり速 度分布の生じる二次元ポアズイユ流れを用いる. 従来の研究 からスタートアップ流れなどの過渡的な状況において構造 変化や不安定性の影響が強く現れることから, 時間的な過渡 的効果として停止状態から突然ある一定の駆動圧力で流動 を開始するスタートアップ流れを適用し, 空間的な過渡的効 果として二次元急縮小部を有する流路を使用した. このよう な流れ場において急縮小部近傍における白濁の発生を, 高速 度カメラを用いて詳細に観察する. また, 流量の時間的変化 を測定し, SISの発生と流動抵抗の関係を検討する.

\section{2. 試料および実験装置}

\section{1 試料}

本実験ではカチオン系界面活性剤である cethyltrimethylammonium bromide (CTAB ; 東京化成工業) に塩 として sodium salicylate (NaSal ; SIGMA社) を添加した水溶液 を使用した. CTABの濃度を $0.03 \mathrm{M}, \mathrm{NaSal}$ の濃度を $0.23 \mathrm{M}$ と してイオン交換水に溶解した。 この濃度は四方らのをはじめ として多くの研究者が研究に使用しているものと同じであ り, 既知の結果との比較の容易さを考慮して決定した. 流動 状態を可視化するために直径 $63 \sim 83 \mu \mathrm{m}$ のナイロン粒子を $6.25 \times 10^{-3} \mathrm{wt} \%$ の割合で混入させた. すべての実験は室温 $25 \sim 27{ }^{\circ} \mathrm{C}$ において行なわれた. Fig.1に今回使用したCTAB/ $\mathrm{NaSal}$ 水溶液の定常粘弾性試験の結果を示す.これはひずみ制 御型レオメータ（ARES ; Rheometric Scientific.Ltd）を用い, 直 径50 mmの円錐円板型流路を用いて測定した.

また, 比較のために構造変化を生じない高分子溶液を用い
た. 試料はn-Tetradecane（東京化成工業）にポリイソブチレン (PIB ; Exxon Chemicals) を5 wt\%で溶解したものである.

\section{2 実験装置}

Fig.2 に二次元急縮小流路の詳細を示す．縮小比は 4:1であ る. 二次元性を確保するために流路幅と高さの比を上流部に おいて 10:1，下流部で40:1 とした。 Fig.3に実験装置全体の概 略を示す.テストセクションである二次元急縮小流路は同じ 幅で作られた上流リザーバと下流リザーバに直結されてい る.上流および下流リザーバにおける液面が二次元急縮小流 路よりも十分に高い位置となるよう十分な量の試料が装置 内に満たされている．上流および下流リザーバの双方にコン プレッサで調整された等しい圧力を加えておき，下流リザー バに設置されているスタートアップバルブを瞬時に開放す ることにより所定の圧力差をステップ状に発生させる. 下流 リザーバの上部にはレーザ変位計が設置されており，液面に 浮かべてあるターゲットの移動量から流量の時間変化を算 出する．上流・下流リザーバおよび二次元急縮小流路は透明

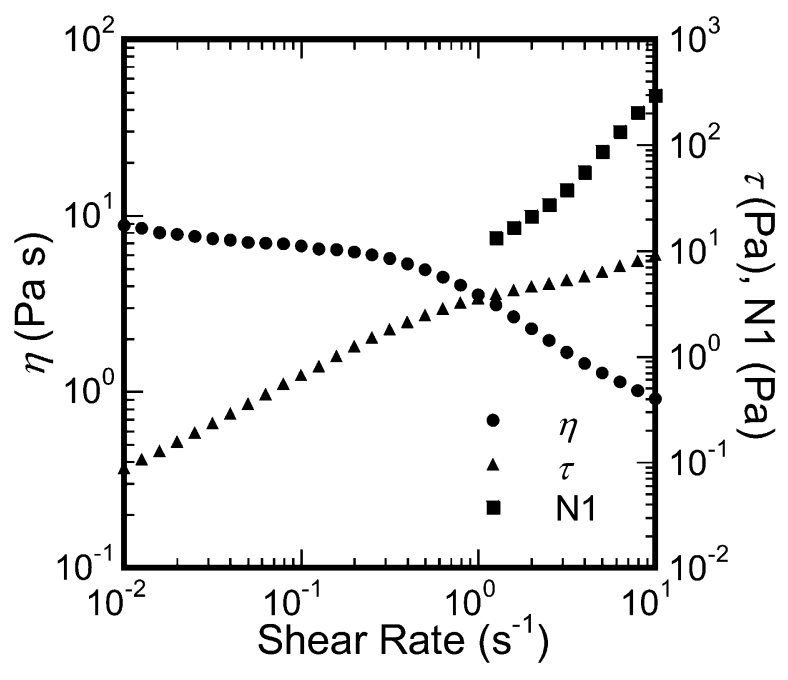

Fig. 1. $\operatorname{Viscosity}(\eta)$, shear $\operatorname{stress}(\tau)$ and first normal stress difference $(N 1)$ as a function of shear rate.

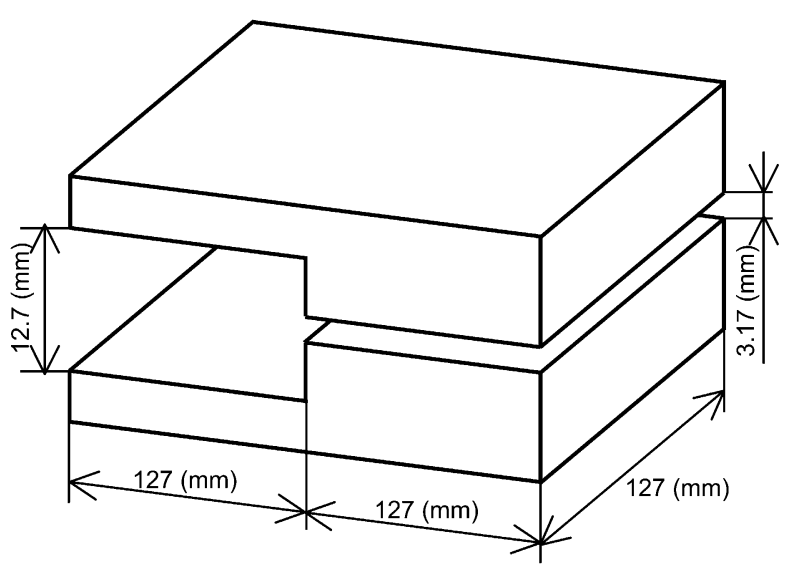

Fig. 2. Dimension of two-dimensional contraction channel. 
なアクリル樹脂で製作されている. 二次元急縮小流路の側壁 面は流れの可視化のために光学ガラス製とした.

流れ場の様子は高速度カメラにより撮影した。撮影時の フレームレートは 250 1/s, シャッタースピードは $1 / 2000 \mathrm{~s}$ と した.

\section{3. 結果および考察}

流量測定 : Fig.4に所定の圧力差をステップ状に与えたス タートアップ流れにおける流量の立ち上がり挙動を示す. 圧 力差が最も低い $0.98 \mathrm{kPa}$ では流量は時間経過とともに徐々に 増加し定常に達する. 一方, これよりも高い駆動圧力 $1.96 \mathrm{kPa}$ で流動させた場合, 流動開始直後からある時間までは $0.98 \mathrm{kPa}$ の場合と同様にゆっくりと流量が増加していくが，ある時間 （Fig.4 矢印）に流量の増加速度が急激に速くなる. その後 さらに時間が経過すると流量は定常值に達し, 変化しなくな る.n-テトラデカンにポリイソブチレンを $5 \mathrm{wt} \%$ の割合で溶解 した高分子溶液を用いて同様の実験を行ったところ, Fig.5に

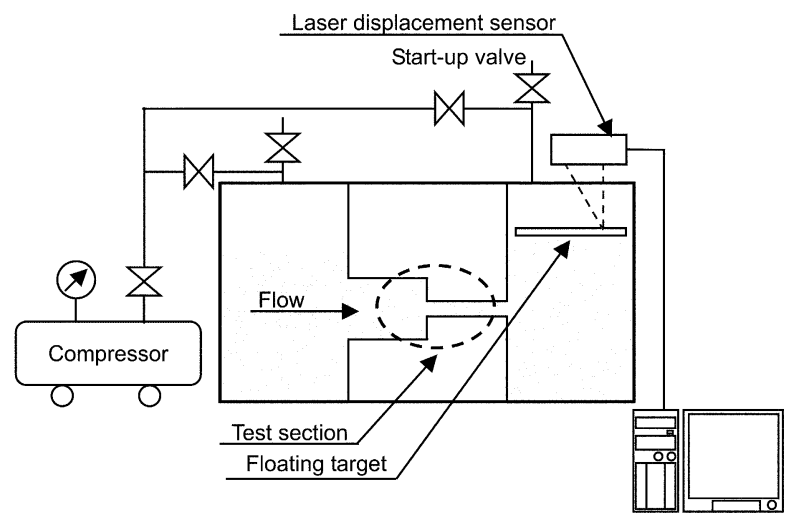

Fig. 3. Schematic diagram of experimental apparatus.

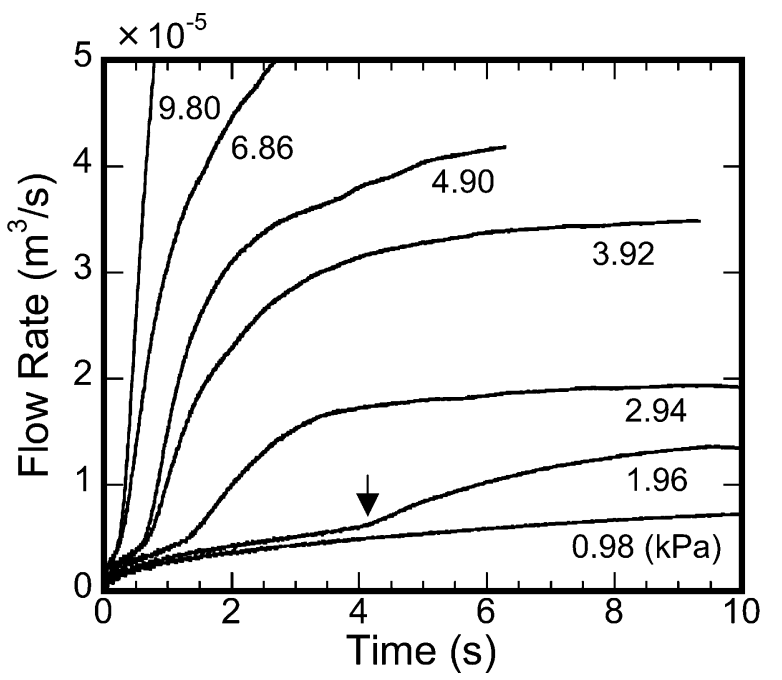

Fig. 4. Start-up behavior of flow rate with constant driving pressure.
示すように駆動圧力に関係なく流動開始直後から流量は 徐々に増加しオーバーシュートを経た後定常值に達した。こ れはずり流動化を示す一般的な粘弾性流体のスタートアッ プ挙動と見なせる結果である. したがってFig.4に示すような 流量の増加曲線に現れる不連続的な変化は界面活性剂水溶 液に特有の特異な挙動であると考えられる.

各設定圧力において流動開始から流量の増加速度が急激 に早くなるまでの時間を臨界時間 $t_{\mathrm{c}}$ とする. Fig.6に $t_{\mathrm{c}}$ と駆動圧 力の関係を示す. Fig.6より $t_{\mathrm{c}}$ は駆動圧力の増加とともに急激 に小さくなり，8kPa近傍で一定值に達する.

可視化実験 : 流量の急激な変化と流れ場の関係を明らかに するために, 二次元急縮小部近傍の流れの可視化を行った. Fig.7に流量の急激な変化が生じなかった駆動圧力 $0.98 \mathrm{kPa} の$ 流れ場の様子を示す。それぞれの写真が撮影された瞬間を流 量-時間曲線上に示した. Fig.7の各写真において左から右に向 かって試料は流動する．左側の広い部分が上流部で右側の狭

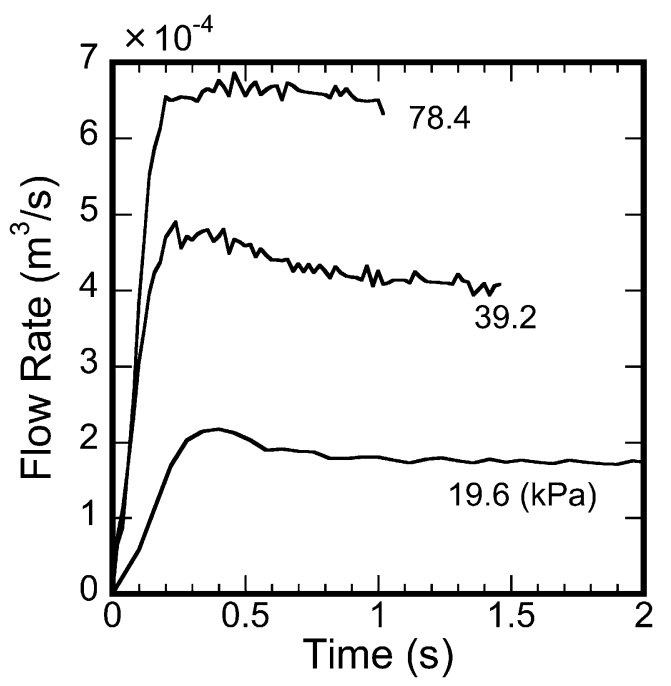

Fig. 5. Start-up behavior of flow rate for $5 \mathrm{wt} \%$ solution of polyisobutylene in tetradecane.

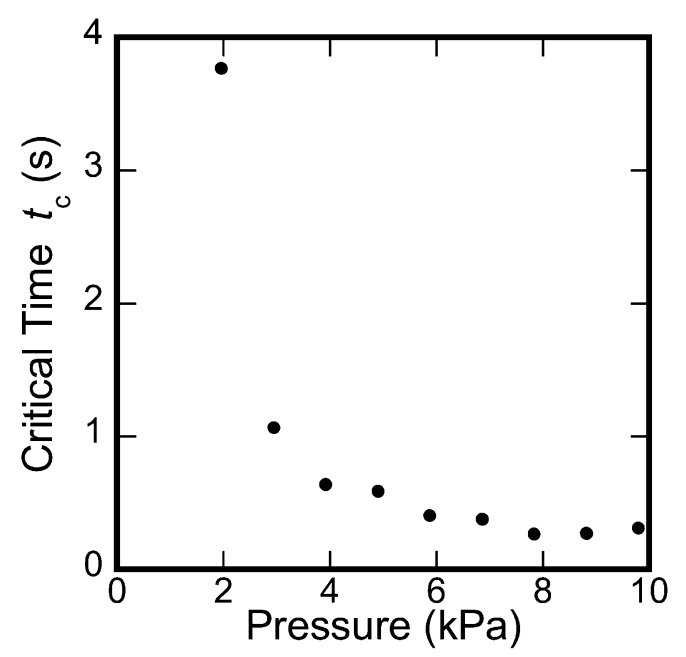

Fig. 6. Critical time $t_{\mathrm{c}}$ of flow rate increasing as a function of driving pressure. 
い隙間が下流部である. カメラと反対側の流路側面に黒いス クリーンを背景として設置して撮影を行ったため, 流路内が 黒く見える場合は試料が透明な状態であることを意味する. また, 試料中の白い点は流動状態を可視化するために試料に 混入したトレーサ粒子である. Fig.7(a)に示すように流動開始 直前の静止状態では流路内が全体にわたり黒く, 試料はほぼ 透明であることを意味する。流量増加の不連続性が発生しな い駆動圧力 $0.98 \mathrm{kPa}$ の場合では時間経過によらず平板間全体 で透明な状態が維持された。

Fig.8に駆動圧力を $9.80 \mathrm{kPa}$ に設定した場合の流れ場の様子 を示す. Fig.8(a)は流動開始前の状態で，試料は透明である. 流動開始直後から臨界時間 $t_{\mathrm{c}}$ に達するまではFig.8(b) (f)に示 すように急縮小部近傍から下流に向かって壁面に沿ってく さび形の白濁領域が形成される. 時間経過に伴い, 白濁領域 は下流側へ成長し, 白濁の度合いも強くなっている様子がわ かる.この白濁は壁面近傍のせん断流動により誘起された構 造, 寸なわちSISが発生したことを意味する。この試料の場 合ずり速度が $4 \mathrm{~s}^{-1}$ 以上でかつひずみ量が 4 を超えたときに SIS が発生する。この臨界ひずみ量4という值はずり速度の值に あまり影響を受けない。急縮小部近傍の助走区間では壁面に よるせん断の影響が徐々に中心部に向かって発達していく ことから，せん断ひずみがあるしきい值を超えるまでに要す る距離は壁面から流路中心に向からほど長くなる.この結果 としてSISの発生領域がくさび形になると考えられる.

さらに時間が経過し， $t_{\mathrm{c}}$ を超えた直後の流れ場の様子を Fig.8(g)に示す. Fig.8(g)の下部壁面右側に見られるように壁面 近傍に形成されていた白濁領域は壁面近傍よりも中心近く により白い層状の構造をとり, それが壁面からはがれるよう に崩壊する。これは壁面近傍での強いせん断とひずみの蓄積 が壁面近傍の薄い層で不安定流動を誘起し, 応力を緩和させ 試料を透明に戻したものと考えられる. この時間の後, Fig.8(h)に示すように平板間全体の白濁が一瞬緩和し, 平板間 全体にわたって白濁の発生と再透明化が各所で不規則に観 察される不安定な流れ場へと遷移する.

くさび形の白濁領域の崩壊から, 不安定流動の発生と同時 にFig.8(i)，(j)に示すように急縮小部上流の流入領域で強い白 濁が形成され, 流入直後は上下平板の隙間全体にわたり強く 白濁した状態となる. 流路高さ全体にわたって均一に発生す ることからこの白濁は上流部での伸張流動により誘起され た構造であると考えられる. Fig.8(j)から下流部の白濁が徐々 に薄くなることが観察されるが，これは伸張流動場からせん 断流動場一の移行の過程と考えられる. 界面活性剂水溶液の 平面伸張流動により誘起される構造変化についてはまだほ とんじ報告がなされておらず興味深い現象である。しかし, 二次元急縮小部の流れは複雑であり, 不安定になりやすい. このため平面伸張流動による流動誘起構造変化の発生を定 量的に議論するにはこの流れ場は適さないと考える. 平面伸 張流動誘起構造変化についてはより適切な流れ場を用いた 詳細な観察を行うべきであり, 本報告ではこれ以上の言及は 行わない.

次に白濁化の発生を定量的に評価するため, 流路内の急 縮小部から $20 \mathrm{~mm}$ で, 下部壁面から $0.1 \mathrm{~mm}$ の位置における 輝度を映像から読みとった。輝度は画面の白さを表し, 背 景である黒いスクリーンとの比較から白濁化の度合いを評 価できる.
流動中の各時刻における輝度 $B$ を流動開始直前の輝度 $B_{0}$ で 除して正規化した值 $B / B_{0}$ の時間的変化をFig.9に示す. Fig.9に おいて $B / B_{0}$ が1のときは白濁化が生じておらず，1より大きい 場合は白濁したことを示す．駆動圧力が最も低い $0.98 \mathrm{kPa}$ の 場合には $B / B_{0}$ はほぼ1のまま変化しない. したがって白濁は生 じていないことがわかる，一方，駆動圧力が $3.92 \mathrm{kPa}$ を越え ると， $B / B_{0}$ が最も大きくなるピークが現れる. ピーク発生時 刻は駆動圧力の増加に伴い早くなり， $B / B_{0}$ の值は駆動圧力の 増加に伴い大きくなる. また, ピークを示した後 $B / B_{0}$ は, 急 激に減少する。 $B / B_{0}$ がピークとなる時刻は流量の増加速度が 急激に早くなる臨界時間 $t$ c 一一致する. 寸なわち, 流量が急 に増加する現象は流入部に形成されるくさび形領域の崩壊 に起因すると考えられる.

SIS の発生と粘度の変化の関係を知るために本実験で使用 した試料のスタートアップ流れにおけるせん断粘度の過渡
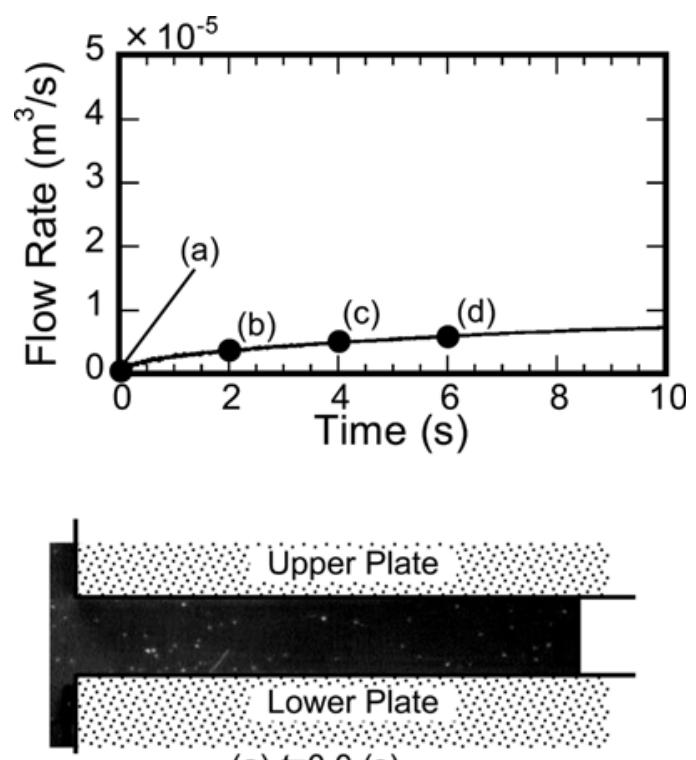

(a) $t=0.0$ (s)

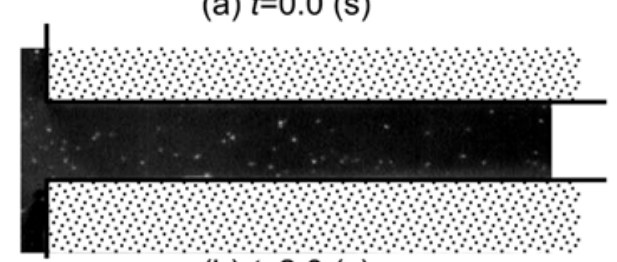

(b) $t=2.0$ (s)

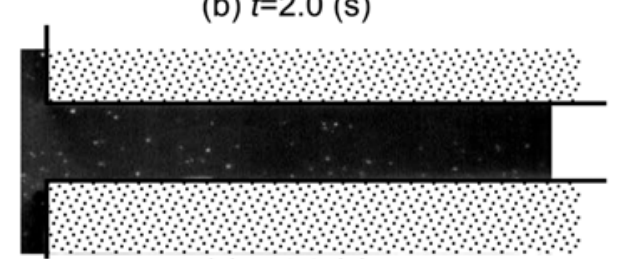

(c) $t=4.0(\mathrm{~s})$

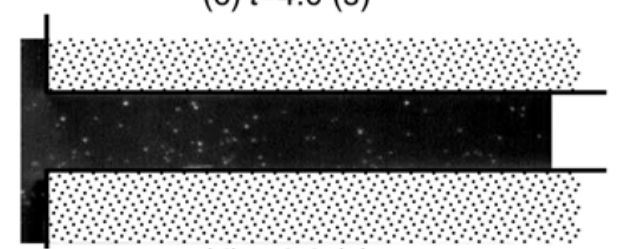

(d) $t=6.0(\mathrm{~s})$

Fig. 7. Start-up behavior of flow rate with driving pressure $0.98 \mathrm{kPa}$ and photographs of flow field near entrance. 
的挙動を測定した．同心二重円筒型流路を光学ガラスにより 作成し，上記の二次元流路に対する測定と同じ方法でSISに よる輝度の変化をせん断粘度と同時に測定した. ${ }^{8)}$ その結果を Fig.10に示す. 正規化された輝度 $B / B_{0}$ とせん断粘度はひずみの 増加とともに急激に増加し，これらの変化は一致している。 粘度が最大值を示すひずみと $B / B_{0}$ がピークを示すひずみも同
時である．この結果より白濁化の発生は粘度の増加に対応す ることがわかる. Fig.8(e), (f)および(g)の写真を見ると, くさ び形の白濁領域は他の部分とは明確に区別できるほどコン トラストが高い. すなわちこの領域はまわりの領域に対して 不連続的といえるほど高粘度になっていると思われる.

この結果より, Fig.4で示した流量増加速度の急激な増加は
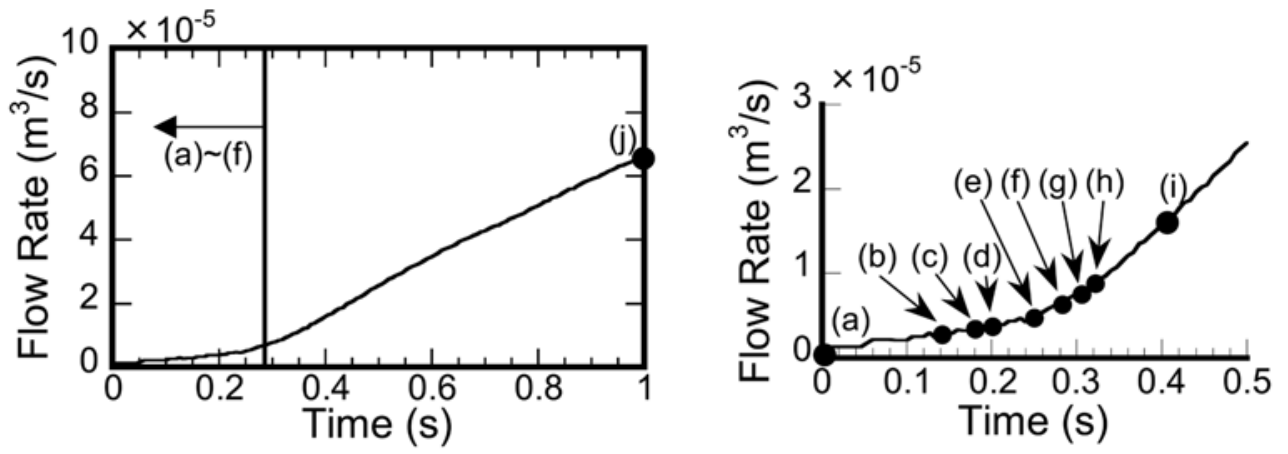

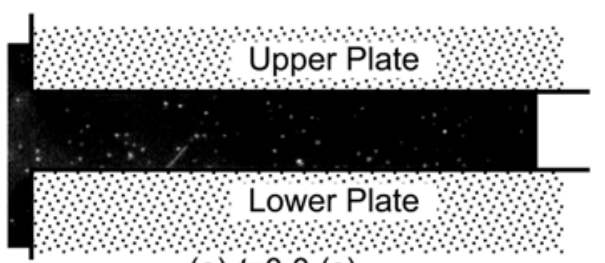

(a) $t=0.0$ (s)

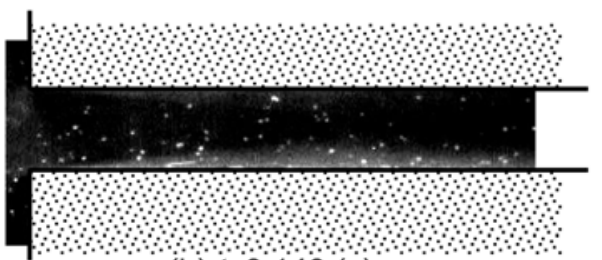

(b) $t=0.140$ (s)

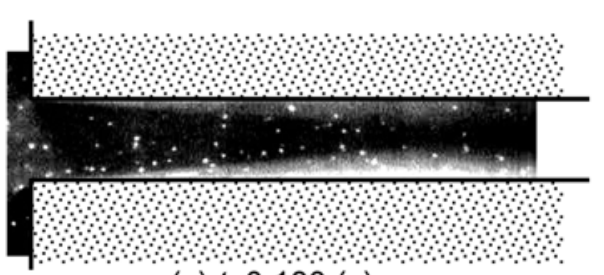

(c) $t=0.180$ (s)

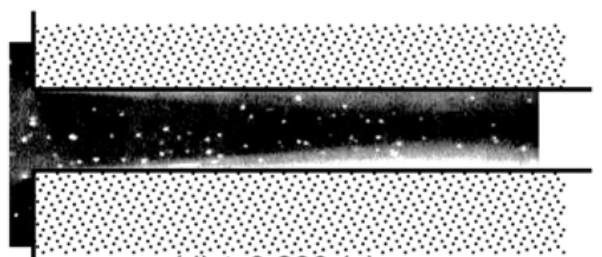

(d) $t=0.200(\mathrm{~s})$

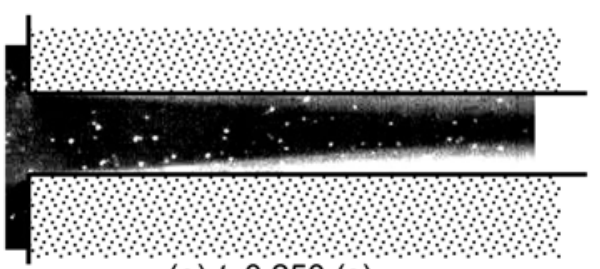

(e) $t=0.250(\mathrm{~s})$

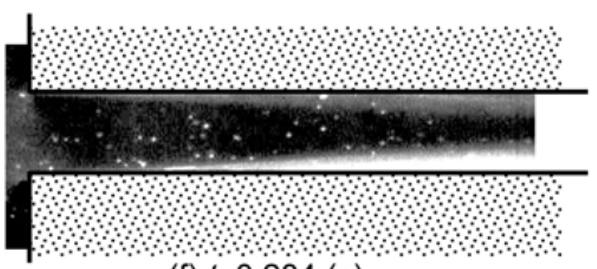

(f) $t=0.284$ (s)

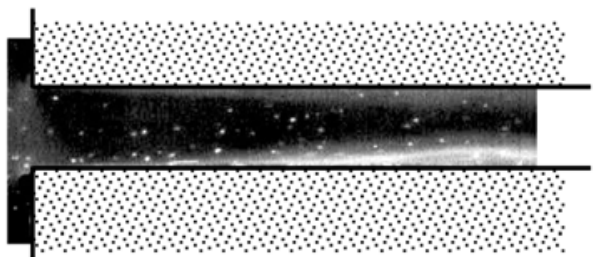

(g) $t=0.304$ (s)

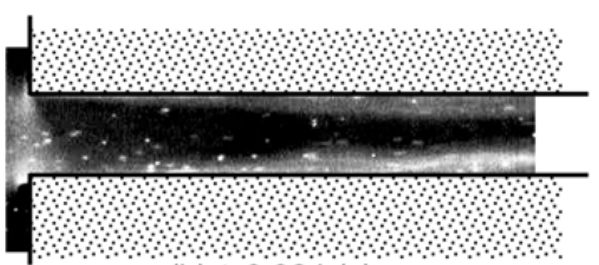

(h) $t=0.324(\mathrm{~s})$

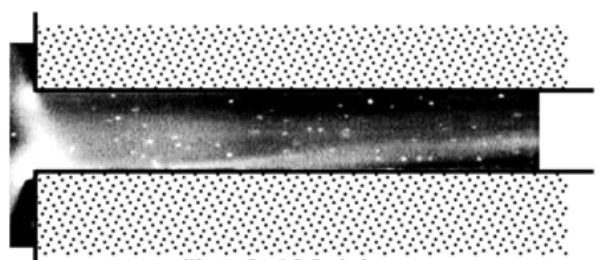

(i) $t=0.400$ (s)

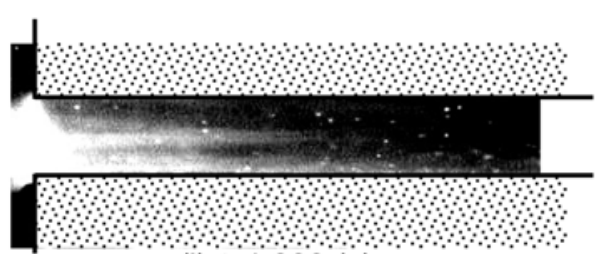

(j) $t=1.000(\mathrm{~s})$

Fig. 8. Start-up behavior of flow rate with driving pressure $9.80 \mathrm{kPa}$ and photographs of flow field near entrance. 


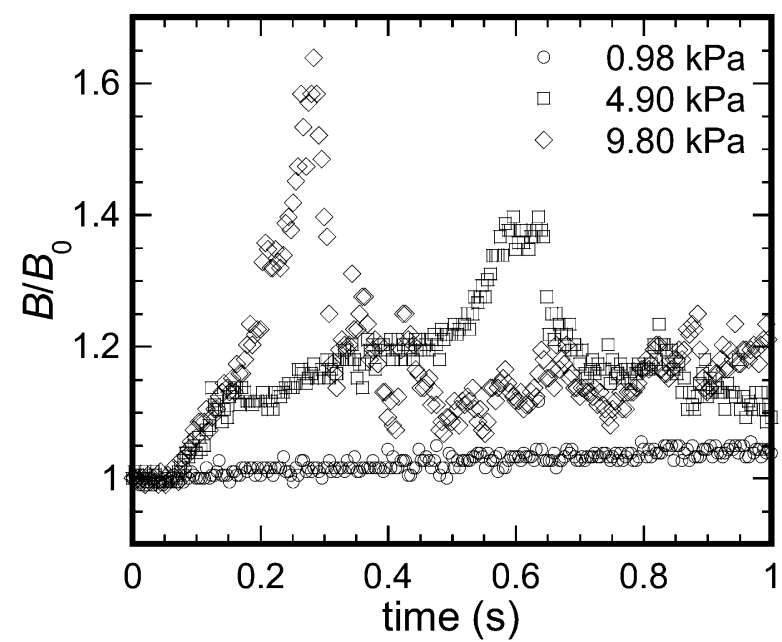

Fig. 9. Normalized brightness $B / B_{0}$ at the each driving pressure vs. passage time.

以下のように定性的に説明される. 寸なわち, $0<t<t$ の範囲で は流動開始とともに高粘度のくさび形領域は次第に流路中 心面に向かって拡大し, 主流である構造変化していない流体 が流動する領域が減少していく，これにより流動抵抗が増加 し流量の立ち上がりが阻害される.SISにより形成された白濁 領域はFig.10でわかるように最大值を迎えた後に突然消滅 し, 粘度が低下寸る. 二次元急縮小流れの場合は $t=t_{\mathrm{c}}$ でくさ び形領域が最大となった後, 突然その領域が消失する.これ により流量が急増すると考えられる．また， $t_{\mathrm{c}}$ はFig.6に示す ように駆動圧力を増加すると小さくなる.これはSIS 発生に 必要なひずみの蓄積に要する時間が短くなることに起因す ると考えられる. 以上のようにSIS を発生する界面活性剤水 溶液の急縮小流れでは流入部において構造変化に伴う流動 抵抗の時間的変動が発生し流れ場全体に対して影響を及ぼ すため, 構造変化を生じない一般の流体とは異なる取り扱い が必要である.

\section{4. 結 論}

本研究では二次元急縮小流路における界面活性剂水溶液 の駆動圧力一定のスタートアップ流れの観察を行い, 流動誘 起構造変化の発生と流量の過渡的挙動について以下の結論 を得た。

1) 流量は流動開始から緩やかに立ち上がるが，駆動圧力が大 きいとき，ある時間を境にして増加速度が急激に速くな る。これは高分子溶液においては発生しないSIS を生じる 界面活性剤水溶液特有の現象である。

2) 上記の流量増加の急激な変化が見られる場合, 流動開始か らある時間経過すると, 流入部壁面近傍にくさび形の白濁 領域が形成され時間とともに成長する.ささらにある時間を 経過するとその領域内で不安定流動が発生しこの領域が

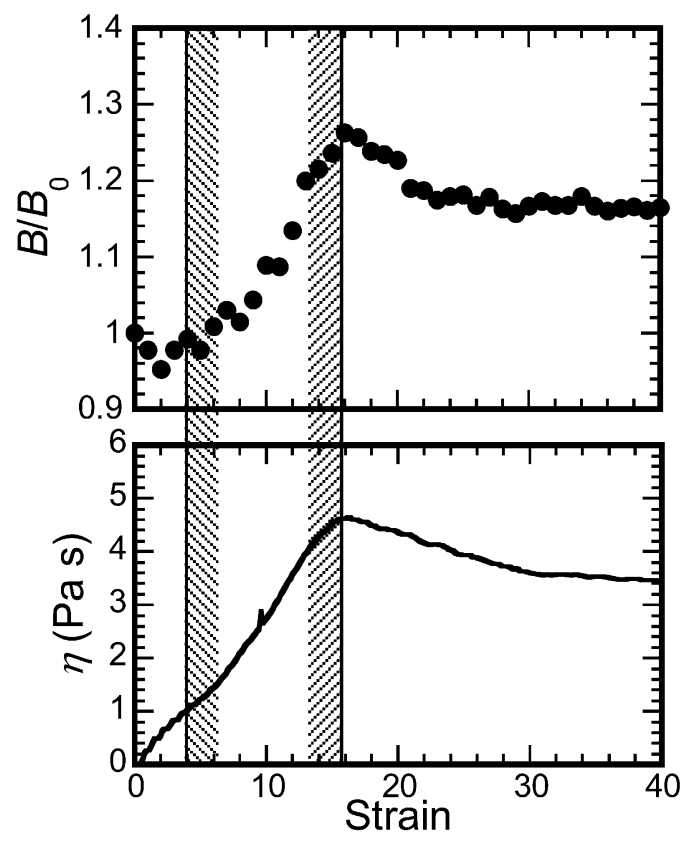

Fig. 10. Normalized brightness $B / B_{0}$ and shear viscosity on Couette flow using concentric cylinder flow cell.

消滅する. 上記の流量増加量の急激な変化はこれに対応し ている.

3) 流動開始から流量の増加量が急激に変化するまでの時間 は駆動圧力の増加に伴い急激に短くなり，ある圧力以上で ほぼ一定值となる。

\section{REFERENCES}

1) Shikata T, Hirata H, Kotaka T, Langmuir, 3, 1081 (1987).

2) Shikata T, Hirata H, Kotaka T, Langmuir, 4, 354 (1988).

3) Kadoma IA, Ylitalo C, van Egmond JW, Rheologica Acta, 36, 1 (1997).

4) Rehage H, Wunderlich I, Hoffmann H, Progress in Colloid \& Polym Sci, 72, 51 (1986).

5) Wunderlich I, Hoffmann H, Rehage H, Rheologica Acta, 26, 532 (1987).

6) Shikata T, Dahman SJ, Pearson DS, Langmuir, 10, 3470 (1994).

7) Fischer P, Wheeler EK, Fuller GG, Rheol Acta, 41, 35 (2002).

8) Ouchi M, Takahashi T, Shirakashi M, J Rheol, 50, 341 (2006).

9) Wheeler EK, Izu P, Fuller GG, Rheologica Acta, 35, 139 (1996).

10) Wheeler EK, Fischer P, Fuller GG, $J$ Non-Newtonian Fluid Mech, 75, 193 (1998).

11) Fischer P, Rheologica Acta, 39, 234 (2000).

12) Takahashi T, Yako N, Shirakashi M, Nihon Reoroji Gakkaishi, 29, 27 (2001). 